\title{
Does Slow and Variable Recovery of Diadema antillarum on Caribbean Fore-Reefs Reflect Density-Dependent Habitat Selection?
}

\author{
Alice Rogers ${ }^{1 *}$ and Kai Lorenzen ${ }^{2}$ \\ ${ }^{1}$ Marine Spatial Ecology Lab, School of Biology, University of Queensland, St Lucia, QLD, Australia, ${ }^{2}$ Fisheries and Aquatic \\ Sciences, School of Forest Resources and Conservation, University of Florida, Gainesville, FL, USA
}

\section{OPEN ACCESS}

Edited by:

Eric Jeremy Hochberg, Bermuda Institute of Ocean Sciences, Bermuda

Reviewed by: Aldo Cróquer,

Simon Bolivar University, Venezuela

Jeffrey S. Shima,

Victoria University of Wellington, New Zealand

*Correspondence: Alice Rogers

a.rogers2@uq.edu.au

Specialty section: This article was submitted to

Coral Reef Research,

a section of the journal Frontiers in Marine Science

Received: 28 August 2015 Accepted: 18 April 2016 Published: 02 May 2016

Citation:

Rogers A and Lorenzen K (2016) Does

Slow and Variable Recovery of

Diadema antillarum on Caribbean Fore-Reefs Reflect Density-Dependent Habitat Selection?

Front. Mar. Sci. 3:63. doi: 10.3389/fmars.2016.00063
Recovery of the Caribbean long-spined sea urchin Diadema antillarum from the pathogen-induced mass mortality event of 1983 has been slow and variable. Multiple studies indicate that post-mortality population densities are greatest in sheltered lagoon and back reef habitats, and that recovery is limited on forereefs where pre-mortality densities were also high (Miller R. J. et al., 2003; Van der Hal, 2005; Debrot and Nagelkerken, 2006; Steiner and Williams, 2006; Vermeij et al., 2010). We carried out detailed surveys of a recovering population of $D$. antillarum in Curacao to document an ongoing influence of habitat type on population density, and to explore what ecosystem characteristics might drive observed recovery patterns. We quantified $D$. antillarum population density, larval settlement rates, herbivorous fish biomass, algal turfs, macroalgae, and predatory fish biomass in sites with and without structural complexity on reefs in sheltered lagoon and backreef locations, and on the forereef, using an orthogonal survey design. $D$. antillarum densities were greatest in sheltered lagoon and backreef locations, with high structural complexity. However, densities were significantly lower than those reported prior to the mass mortality event. Larval settlement rates were greater in sheltered lagoon and backreef locations but did not fully account for observed patterns in urchin density. Sheltered lagoon and backreef habitats had more turf algae and fewer herbivorous fish than forereef habitats. Predator abundance was generally low and did not differ significantly among habitat types. In light of our results, we hypothesize that patterns of $D$. antillarum recovery in Curacao are consistent with dynamics expected in the presence of density-dependent habitat selection. More algal resources and fewer herbivorous fish provide a mechanism for increased fitness and habitat suitability in sheltered, lagoon, and backreef habitats. Forereefs, by contrast, offer reduced habitat suitability and, we hypothesize, will only be re-colonized once the carrying capacity of more favorable habitats is exceeded. We propose a number of testable predictions to explore this theory further, and advocate for including sheltered lagoon and backreef habitats in D. antillarum population surveys to monitor recovery, as well as protecting populations found in these habitats where necessary. We predict that when current 
populations return to pre-mortality densities, range expansion may allow for a return of D. antillarum to Caribbean forereefs.

Keywords: recovery dynamics, density-dependent habitat selection, Diadema antillarum, larval settlement, Caribbean

\section{INTRODUCTION}

The long-spined sea urchin Diadema antillarum is a keystone species on Caribbean coral reefs, and its grazing and bio-eroding behaviors act as a significant structuring force on the benthic community (Sammarco, 1982a). In 1983 a mass mortality event greater than any other recorded for a marine species, reduced D. antillarum populations by more than $95 \%$ across its entire range (Lessios et al., 1984; Lessios, 1988a). In the decades that followed, Caribbean coral reefs exhibited significant declines in health, specifically overgrowth of fleshy macroalgae and reduced live coral cover (Carpenter, 1985, 1990a; Gardner et al., 2003). The mortality of $D$. antillarum was not the only cause of this so-called phase shift. The region also suffered disturbance from storms (Bries et al., 2004), bleaching events (Aronson et al., 2002), coral disease and overfishing (Aronson and Precht, 2000) during this time. However, the return of D. antillarum has been demonstrated to reduce macroalgae, free up bare substrate and promote coral recruitment (Edmunds and Carpenter, 2001; Carpenter and Edmunds, 2006). As a result, D. antillarum population recovery is of great interest to coral reef managers and is widely considered to be an important and positive mechanism to promote reef recovery.

Population recovery of $D$. antillarum has been slow and variable, both at regional (Chiappone et al., 2002; Lessios, 2005; Carpenter and Edmunds, 2006), and local scales (Lessios, 1988b; Edmunds and Carpenter, 2001; Cameron and Brodeur, 2007). Our understanding of the biological processes and ecosystem characteristics driving recovery dynamics are limited, and our attempts to manage and promote it, have been largely unsuccessful (Miller M. W. et al., 2003; Nedimyer and Moe, 2003; Dame, 2008). Here, we carried out an extensive field study on the Caribbean island of Curacao, one of few locations demonstrating signs of $D$. antillarum recovery in recent years (Debrot and Nagelkerken, 2006; Vermeij et al., 2010). D. antillarum populations in Curacao are patchy, and previous research on the island, prior to, and since the mass mortality event (Bak et al., 1984; Teenstra, 1986; Debrot and Nagelkerken, 2006; Vermeij et al., 2010), makes it an ideal location for studying recovery patterns, spatial distributions, and the finescale processes and ecosystem characteristics that are responsible for driving them. Pre-mortality population densities in Curacao were much the same as those reported elsewhere in the region, ranging from 3 to 20 individuals per square meter (Bak and Vaneys, 1975; Bauer, 1980; Bak, 1985), and though densities were variable in space [specifically being far fewer on the exposed windward shore and the isolated eastern point of the island (Bak, 1985)], D. antillarum were found in all major habitats from shallow and deep coral reefs (Bak and Vaneys, 1975; Bauer, 1980; Bak et al., 1984) to inland bays (Teenstra, 1986). Disease hit the population on October 6th 1983 and spread to affect the entire island during the following weeks, causing population decreases between 98 and 100\% (Bak et al., 1984). The loss of D. antillarum in Curacao, like elsewhere, preceded a significant increase in fleshy and filamentous algae on shallow reefs (Vansteveninck and Bak, 1986) and a significant decrease in bio-erosion and structural complexity (Bak et al., 1984).

In 2002, an extensive survey was carried out to document spatial patterns in D. antillarum recovery in Curacao (Debrot and Nagelkerken, 2006). Surveys were carried out during daylight hours, and focused on distinct habitat types at different depth gradients; exposed and sheltered reefs and natural and artificial lagoons. In 2005, surveys were carried out under a similar design, examining recovery in deep and shallow water at exposed and sheltered sites (Van der Hal, 2005). These studies showed that population densities overall on the island remained at least an order of magnitude lower than pre-mortality estimates and that recovery was restricted almost entirely to shallow, sheltered habitats. Very few sea urchins were encountered on the forereef or in deeper water where they were previously ubiquitous (Bak and Vaneys, 1975; Bak et al., 1984).

A number of hypotheses have been put forward regarding the biological processes and ecosystem characteristics that prevent $D$. antillarum population recovery. These include larval limitation (Lessios, 1995), reduced larval settlement (Bak, 1985), a reduction in habitat structural complexity, and predation refugia (Lee, 2006; Alvarez-Filip et al., 2009), increased competitor (herbivorous fish) abundance (Carpenter, 1985) and macroalgal overgrowth (Bak, 1985). The question addressed in this study is whether variability in these characteristics is responsible for the spatial patterns of recovery observed in Curacao over recent years. We specifically investigate the prevalence, and population growth of urchins in sheltered lagoon and back-reef habitats, and their scarcity on the forereef. We contribute additional data to a time series of $D$. antillarum surveys that confirm the ongoing recovery pattern and present new data indicating potential mechanisms for increased suitability of sheltered habitats to D. antillarum fitness. We discuss our findings in context of the theory of density dependent habitat selection. The theory states that a dynamic population which has not reached carrying capacity will occupy habitats in an order determined by habitat suitability, i.e., habitats which offer characteristics that increase fitness are occupied first, but as population density increases, intraspecific competition for resources and space drives a reduction in the perceived suitability of these habitats and as a result, the range of the population expands (Fretwell and Lucas, 1969; Fretwell, 1972; MacCall, 1990).

\section{METHODS}

Detailed surveys of the established D. antillarum population of Curacao were carried out between May 25th and August 27th 2010. Table 1 summarizes the hypotheses tested and the data 
TABLE 1 | Summary of the hypotheses tested, data used, and models fitted.

\begin{tabular}{|c|c|c|}
\hline Hypotheses & Data Used & Statistical analysis \\
\hline \multicolumn{3}{|l|}{$\begin{array}{l}\text { The habitat characteristics of (a) habitat type and (b) } \\
\text { structural complexity influence: }\end{array}$} \\
\hline 1. Density of $D$. antillarum & Average $D$. antillarum density per site $(n=20)$ & $\begin{array}{l}\text { GLM; family }=\text { tweedie, } p=1.84: D \text {. antillarum } \\
\text { density } \sim \text { Habitat }{ }^{\star} \text { Complexity }+ \text { Depth }\end{array}$ \\
\hline 2. D. antillarum larval settlement rates & $\begin{array}{l}\text { Average } D \text {. antillarum larval settlement rate (no. } \mathrm{m}^{-2} \text {-day) } \\
\text { per site from } 3 \text { monthly measurements }(n=15)\end{array}$ & $\begin{array}{l}\text { GLM; family }=\text { tweedie, } p=2.62: \text { Larval } \\
\text { settlement } \sim \text { Habitat }\end{array}$ \\
\hline \multicolumn{3}{|l|}{ 3. Ecological factors related to post-settlement fitness } \\
\hline $\begin{array}{l}\text { a. Abundance of } D \text {. antillarum fish predators } \\
\text { (predation) }\end{array}$ & Average biomass density of predatory fish per site $(n=20)$ & $\begin{array}{l}\text { GLM; family = Gamma: Predatory fish biomass } \\
\text { density Habitat }{ }^{\star} \text { Complexity + Depth }\end{array}$ \\
\hline $\begin{array}{l}\text { b. Abundance of herbivorous fish (interspecific } \\
\text { resource competition) }\end{array}$ & $\begin{array}{l}\text { Average biomass density of herbivorous fish per site } \\
(n=20)\end{array}$ & $\begin{array}{l}\text { GLM; family }=\text { tweedie, } p=1.87 \text { : Herbivorous } \\
\text { fish biomass density } \sim \text { Habitat }+ \text { Complexity }\end{array}$ \\
\hline c. Turf algae growth (resource availability) & $\begin{array}{l}\text { Average percent cover of algae on settlement plates after } 8 \\
\text { weeks per site, arc-sin transformed }(n=15)\end{array}$ & $\begin{array}{l}\text { GLM; family }=\text { tweedie, } p=1.83 \text { : Algal percent } \\
\text { cover } \sim \text { Habitat }+ \text { Complexity }\end{array}$ \\
\hline $\begin{array}{l}\text { d. Percent cover of macroalgae (resource } \\
\text { availability) }\end{array}$ & $\begin{array}{l}\text { Average percent cover of macroalgae per site, arc-sin } \\
\text { transformed }(n=20)\end{array}$ & $\begin{array}{l}\text { GLM; family = tweedie, } p=1.99: \text { Macroalgal } \\
\% \text { cover } \sim \text { Habitat }+ \text { Complexity }\end{array}$ \\
\hline
\end{tabular}

collected. All activities carried out within the scope of the study were non-invasive, did not involve endangered, or protected species, and did not require specific permission or permits. Table $\mathrm{S} 1$ in the online supplementary material provides all of the data presented and discussed in this paper.

\section{Study Sites}

Surveys were carried out along the southern leeward shore of Curacao at 20 sites spanning $\sim 50 \mathrm{~km}$ (Figure 1). Table S2 in the Online Supplementary Material provides details of individual study sites with GPS coordinates. Study sites were selected non-randomly to reflect an orthogonal design allowing us to partition the influences of habitat type (sheltered lagoon or backreef versus fore-reef) from habitat complexity (complex versus low-relief). Habitats were selected for compatibility with earlier recovery surveys on the island (Debrot and Nagelkerken, 2006). Sheltered lagoon and backreef habitats (hereafter referred to as sheltered habitats) were hard-bottom and rubble substrates located within or close to natural or artificial bays, while forereef habitats were located on the fringing reef, close to the drop-off zone. Complex and non-complex habitats were selected based on an initial visual assessment, where complex habitats were dominated by structures with relief $>20 \mathrm{~cm}$, and non-complex sites were dominated by low-relief hard substrate including rubble. Rugosity was measured at each site to confirm the clear distinction between habitat types (complex $=1.7 \pm 0.08$, noncomplex $=1.2 \pm 0.02, F=17.5, d f=18, p<0.001$ ). Given prior knowledge that shallow depths are preferential habitat for recovering populations of $D$. antillarum (Carpenter and Edmunds, 2006; Debrot and Nagelkerken, 2006), all surveys were conducted at depths of $6 \mathrm{~m}$ or less. Breakwater habitats were also included as structurally complex, forereef sites in shallow water. At each survey site, transects $25 \mathrm{~m}$ long by $4 \mathrm{~m}$ wide were established and marked $(n=3)$. For each treatment group (sheltered low-relief, sheltered complex, fore-reef low-relief, and fore-reef complex), there was a minimum of three survey sites.

\section{Sea Urchin Census}

Sites were surveyed for population density during daylight hours (0800-1700). Counts were made of all urchins encountered along belt transects and converted to densities per square meter. The time taken to carry out searches was dependent on the nature of the habitat, with more complex environments requiring longer search times to ensure that all urchins were identified. Urchin sizes were estimated to the nearest $5 \mathrm{~cm}$, but because $D$. antillarum smaller than $10 \mathrm{~mm}$ in test diameter are notoriously difficult to survey in the field during the day (Bak, 1985), they were excluded from analyses.

\section{Larval Settlement Rates}

To estimate larval settlement rates of $D$. antillarum, settlement plates were constructed following the design of Bak (Bak, 1985). Each plate consisted of two sheets of plastic egg crate measuring $\sim 60 \mathrm{~cm}$ by $30 \mathrm{~cm}$, with a sheet of white plastic sandwiched between. Settlement plates were pre-conditioned in seawater for a minimum of seven days prior to deployment to allow for the colonization of a natural biofilm. Plates were deployed at 15 of the 20 survey sites between May 25th and June 11 th $(n=3$ per site, see Figure 1 for locations of settlement surveys), the subset being determined by logistical and financial constraints. Deployment of settlement plates was timed in advance of the predicted summer spawning peak in June and July (Bak, 1985), and the order of deployment and monitoring was randomized between habitat types. Plates were attached to the substrate by a buoyed rope $10 \mathrm{~cm}$ above the substrate to ensure that recruits settled from the water column rather than migrating from the substrate (as in Miller et al., 2009). Settlement plates were first checked 2 weeks following their deployment, ensuring that they had been in the water for a total of 3 weeks to obtain the optimum level of bio-fouling for D. antillarum larval settlement (Bak, 1985; Vermeij et al., 2010). Plates were checked at approximately monthly intervals over a 3month period. On each check, all $D$. antillarum discovered were counted and removed. An average rate of settlement based on 


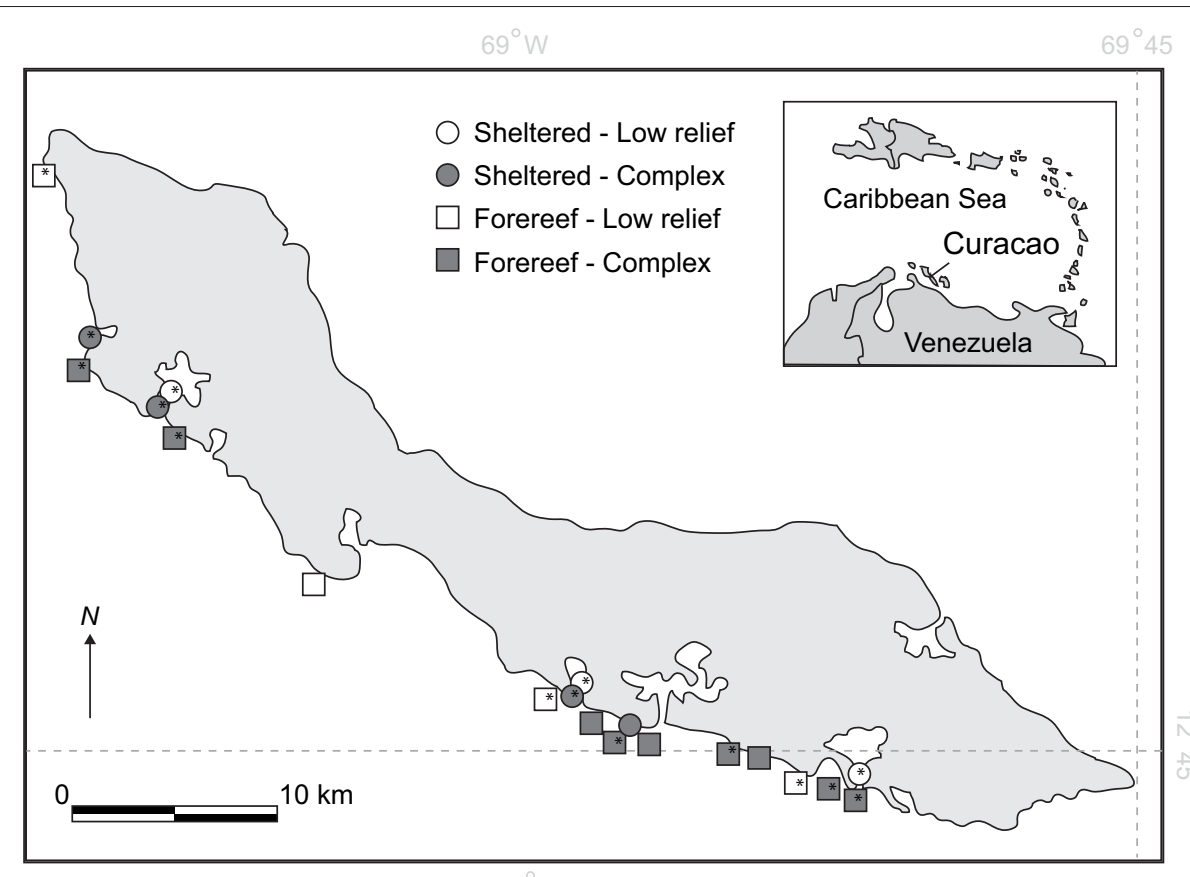

FIGURE 1 | Map of Curacao showing the 20 survey locations on the leeward shore. "Depicts locations where larval settlement plates were deployed.

all three collections was calculated and taken forward for further analyses.

\section{Reef Fish Abundance}

The fish species targeted in surveys included the 15 top predators of D. antillarum identified by Randall (Randall et al., 1964) along with additional species (mainly wrasses) proposed to be D. antillarum predators (pers. comm., Mark Vermeij, Curacao 2010), and common herbivorous species which act as resource competitors (Hay and Taylor, 1985). Fish counts were made along belt transects ( $25 \mathrm{~m}$ long by $4 \mathrm{~m}$ wide) using visual census. A trained SCUBA diver conducted an initial swim, at a speed of $\sim 5 \mathrm{~m}$ per minute to record large, mobile species. This was the first activity carried out, to ensure that fish were not disturbed before they could be counted. A second swim was then made to record all site-attached or cryptic species. All fish lengths were estimated to the nearest $5 \mathrm{~cm}$ and converted to biomass densities using allometric relationships (Bohnsack and Harper, 1988).

\section{Turf Algae Growth}

Settlement plates were used not only to quantify D. antillarum settlement rates, but also to provide a proxy for the variation in turf algae growth between sites. After a period of 8 weeks in the water, photographs of settlement plates were taken, and analyzed using the software package Coral Point Count with Excel extensions (CPCE; Kohler and Gill, 2006). Turf algae was identified using the definition that it is " $1-10 \mathrm{~mm}$ thick, often interspersed with sediment and comprising various species of diatoms, blue-green algae, and simple filamentous representatives of Phaecophycophyta and Rhodophycophyta"
(Carpenter, 1981). Percent cover of turf algae was estimated based on 100 random points overlaying a total area of $864 \mathrm{~cm}^{2}$ from two pictures, one on either side of each settlement plate. This measure reflects net turf algal abundance and takes into account the confounding influence of grazing by herbivorous fish, but not by resident urchins that could not access plates in mid-water.

\section{Macroalgal Abundance}

Percent cover of macroalgae was estimated in 25 randomly distributed $0.25 \mathrm{~m}^{2}$ quadrats along each transect during August 2010. Quadrats were divided into 25 squares (each representing $4 \%$ of the total cover) and the number of squares dominated by fleshy macroalgae was recorded. Results were scaled up to represent percent cover within a transect and percentages were then averaged to give a mean percent cover per site.

\section{Statistical Analyses}

Averages of all response variables were taken at the level of site and taken forward in analyses. Many responses were continuous, but commonly included zeroes. For example, $D$. antillarum, predatory fish and herbivorous fish counts are expressed as population densities, but include instances where there were no individuals. Variables such as these are not well described by common probability distributions, normal, poisson, or gamma, so were instead described by a Poisson-gamma distribution. We used the statistical computing program R, with the package "Tweedie" to estimate probability distributions and fit generalized linear models (GLMs). In line with the factorial experimental design, models were fitted to allow for differences between habitat type (sheltered and forereef) and substrate type 
(low-relief and complex), as well as interactive effects between these attributes. Results reported relate to the minimum adequate model that is also given in Table 1 .

\section{RESULTS}

\section{Population Recovery and Distribution}

Across the 20 sites surveyed on the leeward coast of Curacao, D. antillarum densities varied from 0 to $3.35 \mathrm{~m}^{-2}$. In relation to habitat type and habitat complexity, D. antillarum population densities were significantly higher in sheltered habitats $(1.18 \pm$ $0.45)$, than on forereefs $(0.05 \pm 0.02, p<0.01, d f=19)$ and also on complex $(0.63 \pm 0.29)$ vs. low-relief $(0.10 \pm 0.09)$ substrate $(p<0.01, d f=19)$, with no interaction (Table 2; Figure 2A, error bars represent $95 \%$ confidence intervals). Combining our data with density measurements from past studies in Curacao, we demonstrate that (i) Current population densities remain significantly lower than pre-mortality densities, in any habitat type, indicating that populations are not close to carrying capacity, and (ii) recovery is progressing more quickly in sheltered habitats than on the forereef (Figure 2B, error bars represent \pm 1 standard error).

\section{Larval Settlement and its Relation to Population Density}

D. antillarum larval settlement was variable in space, with significantly higher rates observed in sheltered habitats $(0.86$ $\pm 0.28)$ vs. forereef $(0.24 \pm 0.12)$ locations $(p=0.05, d f=$ 14, Table 2; Figure 3). We did not test for a response in larval settlement to habitat structural complexity because larvae settling on uniform settlement plates will not be influenced by substrate complexity. Our results suggest that sheltered habitats may have higher larval retention or increased larval production. However, there was no significant correlation between larval settlement and population density, which implies that post-settlement processes, including post-settlement survivorship, are also important.

\section{Ecological Factors Influencing Post-Settlement Fitness}

Examining fish communities, macroalgal cover, and turf algae in sheltered and forereef habitats with and without structural

TABLE 2 | Summary of statistical analyses from the study of $D$. antillarum populations and associated population dynamic drivers in Curacao in 2010.

\begin{tabular}{|c|c|c|}
\hline & Habitat type & Substrate \\
\hline 1. D. antillarum population density & ${ }^{* \star}$ Sheltered > Fore-reef & $\begin{array}{l}{ }^{* *} \text { Complex > } \\
\text { Low relief }\end{array}$ \\
\hline 2. D. antillarum larval settlement & ${ }^{*}$ Sheltered > Fore-reef & $\mathrm{N} / \mathrm{A}$ \\
\hline 3a. Predatory fish abundance & Ns & Ns \\
\hline 3b. Herbivorous fish abundance & ${ }^{\star \star \star}$ Fore-reef $>$ Sheltered & Ns \\
\hline 3c. Algal growth & ${ }^{\star \star \star}$ Sheltered > Fore-reef & Ns \\
\hline 3d. Macroalgal percent cover & ${ }^{*}$ Sheltered > Fore-reef & Ns \\
\hline
\end{tabular}

${ }^{\star} p<0.05,{ }^{* \star} p<0.01,{ }^{\star \star \star} p<0.001$, Ns, Not significant; N/A, not applicable (not tested). complexity we found that (i) sheltered habitats had fewer herbivorous fish $(3.90 \pm 1.04$ vs. $17.19 \pm 4.68, p<0.001$, $d f=19)$, more turf algae growth $(31.11 \pm 8.71$ vs. $2.98 \pm$ $1.32 p<0.001, d f=14)$, and higher macroalgal cover $(25.72$ \pm 6.06 , vs. $7.13 \pm 1.95, p=0.01, d f=19$ ), but no difference in predator abundance; and (ii) structural complexity was not related to predators, herbivorous fish, macroalgal cover, or turf algae (Table 2; Figures 4A-D, error bars in figures represent 95\% confidence intervals).

\section{DISCUSSION}

The spatial distribution of D. antillarum populations in Curacao in 2010, when combined with survey data from previous years (Debrot and Nagelkerken, 2006; Vermeij et al., 2010), support the conclusion that recovery is largely restricted to sheltered lagoon and backreef habitats. The same pattern has also been documented elsewhere (Miller R. J. et al., 2003; Steiner and Williams, 2006). In this study, we set out not only to document this continued trend in Curacao, but also to explore the processes likely to drive the pattern and shed light on why D. antillarum continue to be scarce on the forereef where they were once prevalent. Our data allowed us to decouple the effects of habitat type and habitat complexity, demonstrating that each is a driver of $D$. antillarum abundance. We then examined differences in larval settlement rates, and ecological factors influencing postsettlement recruitment and survival among distinct habitat types.

\section{The Role of Larval Settlement}

D. antillarum larval settlement rates and population densities were both greater on average in sheltered versus forereef habitats in Curacao. However, tests for a direct correlation between larval settlement rates and population density were non-significant. It was not possible within the realm of this study to ascertain whether sheltered habitats have higher larval settlement rates due to larval retention or higher production, or whether established populations provide increased settlement cues. Further studies of larval supply and settlement dynamics are important for our understanding of $D$. antillarum recovery, with a key remaining question being, to what extent larval supply and larval retention drive population abundances? In our study, the non-correlation between larval settlement and established populations implies that larval supply is not limiting, and post-settlement processes are also important in determining observed spatial distributions of D. antillarum.

\section{Favorable Characteristics of Sheltered Locations}

On average, we found that sheltered habitats in Curacao had fewer herbivorous fish, higher amounts of algal turf growth, and higher percent cover of macroalgae than exposed fore-reef habitats. Turf algae are the food of choice for D. antillarum (Carpenter, 1981), and represent an informative measure of resource availability. Elevated algal turf growth on settlement plates in sheltered habitats might be attributable to enriched nutrient supply from inland bays or industry on the shore, because these sites are all located closer to shore and to inland 

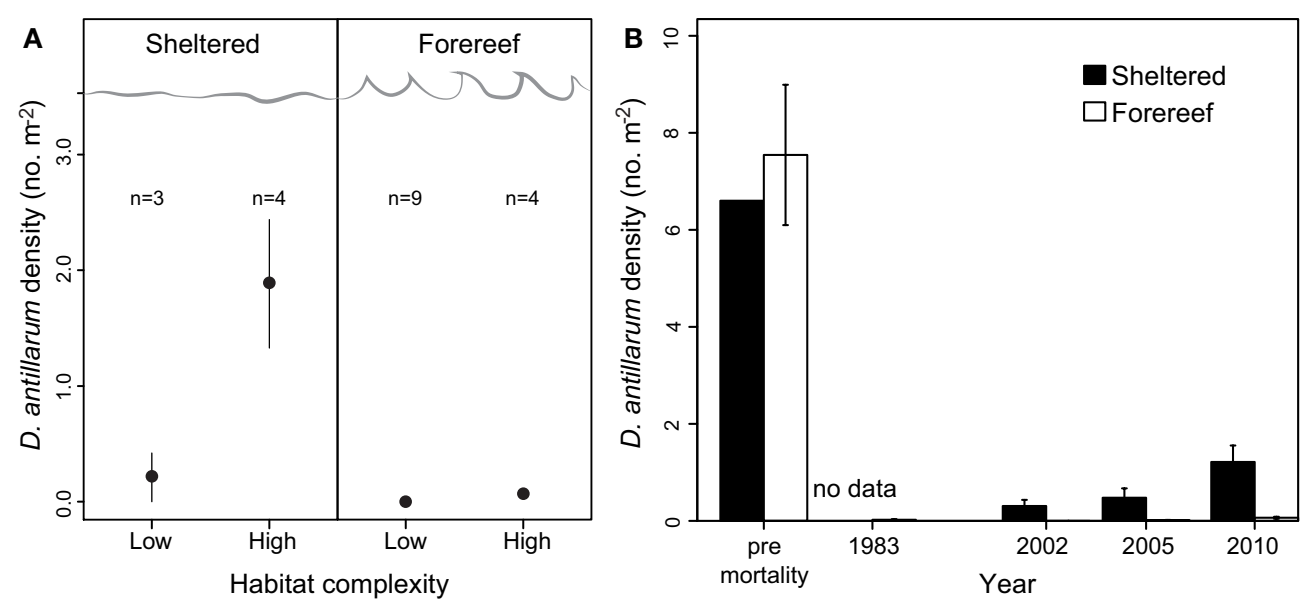

FIGURE 2 | (A) D. antillarum populations in Curacao in relation to habitat type and substrate structural complexity. Error bars represent 95\% confidence intervals and appear absent in forereef locations due to extremely small numbers. (B) Densities of $D$. antillarum in sheltered and fore-reef habitats in Curacao, prior to the mass mortality event, indicating carrying capacity, and at three survey intervals post-mortality; 2002 data from Debrot and Nagelkerken (2006), 2005 data from Van der Hal (2005), and 2010 data from this study. Error bars represent one standard error, and are absent for pre-mortality data in sheltered locations due to a lack of available data.

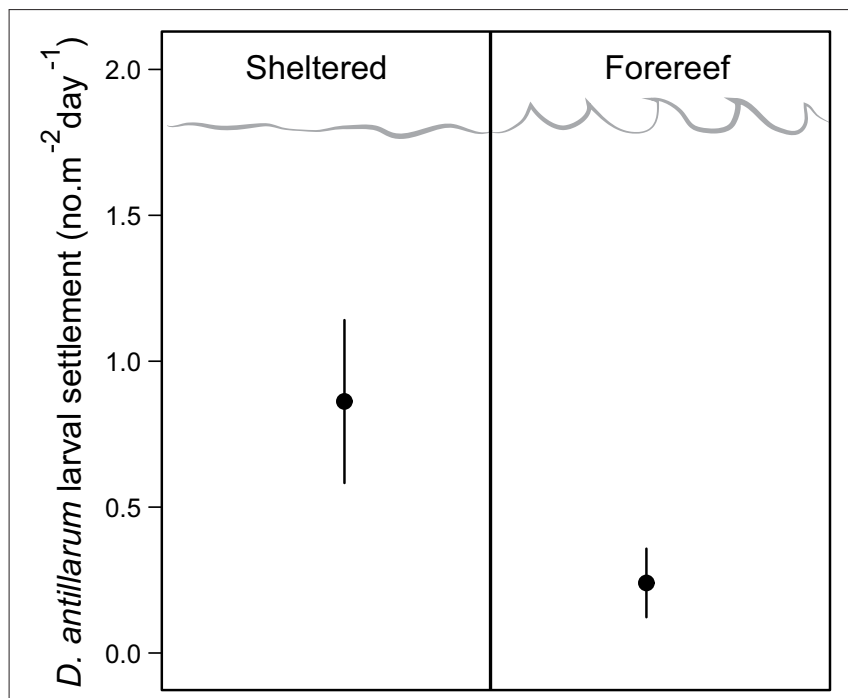

FIGURE 3 | D. antillarum larval settlement rates in sheltered and fore-reef habitats in Curacao. Error bars represent 95\% confidence intervals.

bays than forereef habitats. Quantifying differences in nutrient supply between these habitats is an important next step. It is interesting to note, however, that prior to the 1983 mass mortality event, both Bauer (1980) and Ogden and Carpenter (1987) reported that $D$. antillarum population densities were highest in nutrient enriched locations, close to sewage outlets that had elevated levels of algal growth. Furthermore, Furman and Heck (2008) noted that D. antillarum were seen to migrate onto nutrient enriched treatment patches in their study, suggesting that they are capable of detecting cues from nutrients or from algae, and that they show an active preference for such cues. Our results lend support to both of these studies, raising the possibility that D. antillarum in Curacao favor sheltered lagoon and backreef habitats because they are have more resources. There is, of course, also an interacting influence of herbivory from fish, which were not excluded from grazing settlement plates. Lower herbivorous fish abundance at sheltered locations raises the possibility that interspecific competition plays a role in determining observed distribution patterns. Herbivorous fish can graze just as much, if not more, algae or seagrass than D. antillarum (Hay, 1984; Carpenter, 1985; Furman and Heck, 2008) and have the potential to act as resource competitors (Hay and Taylor, 1985; Carpenter, 1990b). Whether we consider algal turf growth and herbivorous fish abundance independently or in combination, we find that increased resource availability and reduced resource competition are each potential mechanisms for increased suitability of sheltered habitats for D. antillarum in Curacao.

Increased macroalgal cover in sheltered habitats where $D$. antillarum population densities were greatest is somewhat counter-intuitive given the widely reported negative correlation between $D$. antillarum population density and macroalgal abundance due to the impact of grazing (Carpenter, 1986; Hunte and Younglao, 1988; Edmunds and Carpenter, 2001). However, population densities of D. antillarum in Curacao in 2010, even at their highest, were still relatively low. The relationship between urchin density and macroalgal abundance is non-linear, such that macroalgae are only significantly reduced when urchin densities equal or exceed around one individual per square meter (Mumby et al., 2006). Only a handful of locations in Curacao in 2010 had population densities in excess of one individual per square meter, which may explain this result. What is interesting is that our result conflicts with the hypothesis that macroalgae have a 

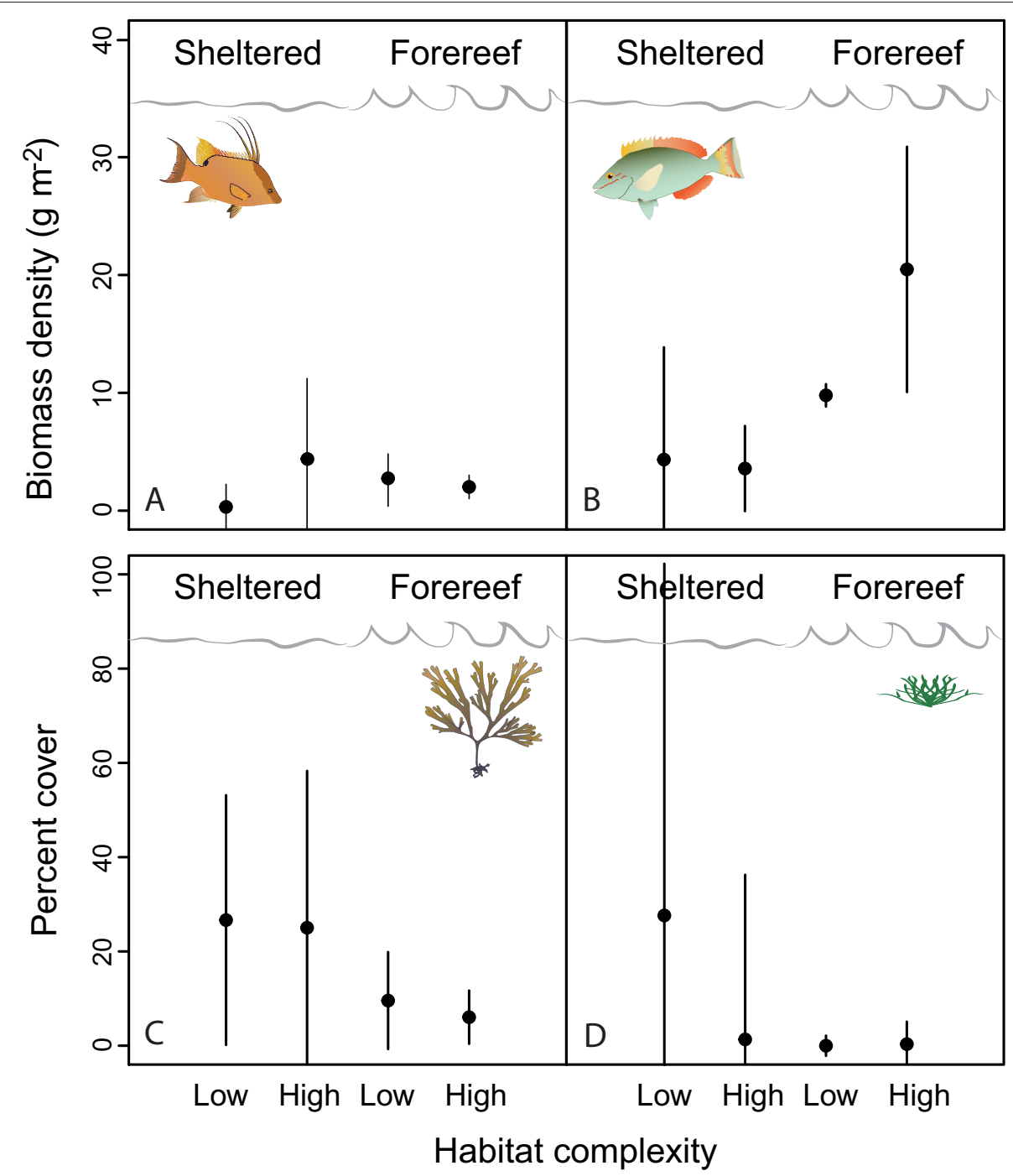

FIGURE 4 | The ecological factors hypothesized to influence D. antillarum post-settlement fitness (A, predators; B, herbivore competitors; C, turf algae on settlement plates; and D, macroalgae). Error bars represent 95\% confidence intervals.

negative impact on D. antillarum larval settlement (Bak, 1985). The hypothesis was put forward by Bak (1985) when he noted reduced settlement rates in locations lacking urchin populations. He did not design his study to determine the mechanism for the difference, but rather suggested that it could be attributable to the build-up of filamentous algae on settlement plates. There have been relatively few other studies of $D$. antillarum settlement in general (but see Miller et al., 2009) and none designed specifically to test the hypothesis. Williams et al. (2011) found that algal "fouling" of settlement plates in their study in Puerto Rico had no significant impact on $D$. antillarum settlement, and Levitan et al. (Levitan, 1988a) found no evidence for increased juvenile recruitment to locations grazed by urchins. Further work is needed to thoroughly test the effect of macroalgae on $D$. antillarum settlement and survival, but our study suggests that, in Curacao at least, macroalgal cover does not have a negative impact on D. antillarum recovery.

\section{The Importance of Structural Complexity}

D. antillarum densities were greater in Curacao in locations with high structural complexity, and this pattern held true even in forereef locations where densities were generally low. This is not surprising given that $D$. antillarum spend most of their time dwelling within crevices during the day to avoid diurnally hunting predators and will abandon areas lacking refugia if a predation risk is perceived (Carpenter, 1984). Positive correlations have been documented between urchin abundance and habitat complexity (Weil et al., 1984), and their survival and persistence following translocations are greatly increased when predation refugia are provided (Dame, 2008). Our experimental design allowed us to decouple the importance of refugia from other confounding ecosystem characteristics that might differ as a result of habitat complexity. We found that structurally complex habitats did not offer any other favorable ecosystem characteristics, when compared to low relief habitats. There was 
no difference in algal turf growth, herbivorous fish abundance, macroalgal cover, or predator abundance. The result reinforces the importance of structural complexity for $D$. antillarum recovery; when all else is equal, urchins do better in habitats with high structural complexity. Given that predator abundance did not differ between habitat types in Curacao, it is likely that habitat complexity is key in mediating predation risk for D. antillarum, and lower population densities of urchins in low-relief habitats can be attributable to an increase in actual predation mortality in the absence of refugia. Identifying shallow reef habitats with high structural complexity along the shore of Curacao was not easy, and coral reefs globally appear to be losing their structural complexity (Alvarez-Filip et al., 2009). This could be a real concern for widespread $D$. antillarum recovery in light of our results. It raises the question of whether Caribbean reefs have changed so much in the past decades that their habitat suitability to $D$. antillarum has reduced.

\section{Evidence for Density-Dependent Habitat Selection}

We propose that the D. antillarum distribution patterns observed in this study, when combined with temporal data (Van der Hal, 2005; Debrot and Nagelkerken, 2006), and observed differences in ecosystem characteristics between habitat types, are in line with expectations from the theory of density-dependent habitat selection (see Fretwell and Lucas, 1969; Fretwell, 1972; Morris, 1989; Shepherd and Litvak, 2004). Our data elucidate potential mechanisms by which sheltered, lagoon, and backreef habitats confer higher levels of fitness on D. antillarum than forereefs. Sheltered habitats have increased turf algae and decreased herbivorous fish, which may translate to increased resource availability. We propose that this difference in habitat suitability is driving the $D$. antillarum population, which has not yet reached carrying capacity in any habitat type (see Figure 2B), to occupy sheltered lagoon and backreef habitats preferentially. Furthermore, given the observed patterns in larval settlement, we identify a mechanism by which this habitat choice is being made. In line with the theory, we predict that only when carrying capacity in sheltered locations has been reached will the populations' range expand to the forereef. Figure 5 shows a graphical representation of the density-dependent habitat selection hypothesis in relation to sheltered and forereef habitats. The mechanism, by which increasing population density will lead to a decline in the quality of sheltered habitats in future, i.e., grazing impact on algae, is well documented. High population densities of $D$. antillarum can rapidly deplete algal resources (Sammarco et al., 1974; Sammarco, 1982a,b) and as resources become limited, D. antillarum shrink in body size (Levitan, 1987, 1988b, 1989). Gamete production is positively correlated with body size (Levitan, 1991), and thus high population density will eventually lead to a reduction in reproductive fitness. Furthermore, D. antillarum are mobile and able to actively select favorable habitats on the scale of tens of hundreds of meters (Lessios et al., 2001). We therefore conclude that there is both pattern and process evidence for a role of density-dependent habitat selection in the recovery dynamics of $D$. antillarum. A number of testable predictions would lend additional support to this hypothesis and improve our understanding of the recovery dynamics of $D$. antillarum: (i) The fitness of D. antillarum is higher in sheltered, vs. forereef locations under current conditions; (ii) Resources for D. antillarum are limited in Curacao (and perhaps elsewhere) in forereef habitats; and (iii) $D$. antillarum larvae can detect and respond to resource availability and preferentially settle in favorable habitats.

\section{Implications for Management}

With respect to management and promotion of $D$. antillarum recovery, we advocate measures to monitor and protect locally dense wild populations, even though they may exist in bays, backreefs, and other "undesirable" locations where their grazing function is not perceived to be important. We recommend including more of these habitat types in population surveys and protecting populations found in them where necessary. In

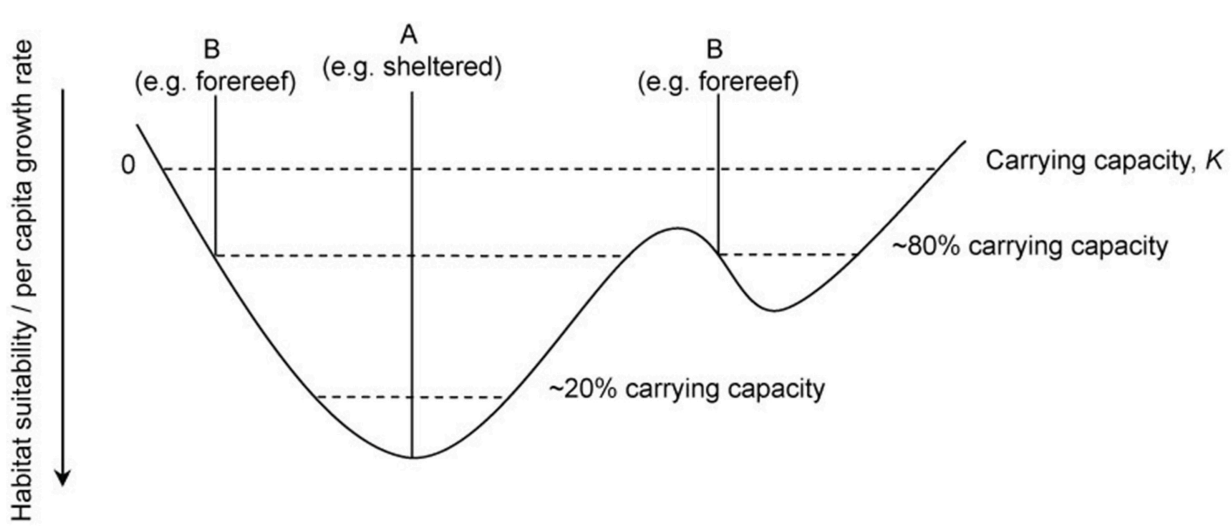

FIGURE 5 | A graphical representation of the Basin Theory of density dependent habitat selection showing how alternative habitat types are occupied depending on overall population size. Habitat suitability and per capita growth rate increases downwards and the irregular, basin-shaped curve represents a continuous topography of habitat suitability where A and B are examples of habitat types. Dashed lines represent population size and carrying capacity, $\mathrm{K}$ is reached when per capita growth rate becomes zero. Figure recreated from MacCall (1990). 
addition, given the observed ubiquitous benefit of complex over non-complex substrates for D. antillarum, the protection, and/or restoration of structural complexity in shallow sheltered and forereef habitats is likely to be essential for widespread population recovery.

\section{ACKNOWLEDGMENTS}

This work was funded by a $\mathrm{PhD}$ scholarship to $\mathrm{AR}$ from the Natural Environment Research Council (NERC). We thank the

\section{REFERENCES}

Alvarez-Filip, L., Dulvy, N. K., Gill, J. A., Cote, I. M., and Watkinson, A. R. (2009). Flattening of Caribbean coral reefs: region-wide declines in architectural complexity. Proc. R. Soc. B Biol. Sci. 276, 3019-3025. doi: 10.1098/rspb.2009.0339

Aronson, R. B., and Precht, W. F. (2000). Herbivory and algal dynamics on the coral reef at Discovery Bay, Jamaica. Limnol. Oceanogr. 45, 251-255. doi: 10.4319/lo.2000.45.1.0251

Aronson, R. B., Precht, W. F., Toscano, M. A., and Koltes, K. H. (2002). The 1998 bleaching event and its aftermath on a coral reef in Belize. Mar. Biol. 141, 435-447. doi: 10.1007/s00227-002-0842-5

Bak, R. P. M. (1985). "Recruitment patterns and mass mortalities in the sea urchin Diadema antillarum," in Proceedings of the Fifth International Coral Reef Congress, Vol. 5 (Tahiti), 267-272.

Bak, R. P. M., Carpay, M. J. E., and Deruytervansteveninck, E. D. (1984). Densities of the sea urchin Diadema antillarum before and after mass mortalities on the coral reefs of Curacao. Mar. Ecol. Progr. Ser. 17, 105-108.

Bak, R. P. M., and Vaneys, G. (1975). Predation of sea urchin Diadema antillarum Philippi on living coral. Oecologia 20, 111-115.

Bauer, J. C. (1980). Observations on geographical variations in population density of the echinoid Diadema antillarum within the Western North Atlantic. Bull. Mar. Sci. 30, 509-515.

Bohnsack, J. A., and Harper, D. E. (1988). Length-Weight Relationships of Selected Marine Reef Fishes from the Southeastern United States and the Caribbean. NOAA Technical Memorandum NMFS-SEFC-215: C-231.

Bries, J. M., Debrot, A. O., and Meyer, D. L. (2004). Damage to the leeward reefs of Curacao and Bonaire, Netherlands Antilles from a rare storm event: Hurricane Lenny, November 1999. Coral Reefs 23, 297-307. doi: 10.1007/s00338-0040379-9

Cameron, C. M., and Brodeur, M. C. (2007). "The abundance of the sea urchins (Diadema antillarum, Echinometra lucunter, and Tripneustes ventricosus) and macroalgae in shallow reef zones of Bonaire," in A Report on the Status of the Coral Reefs of Bonaire in 2007 with Results from Monitoring 2003-2007, eds R. S. Steneck, P. J. Mumby, and S. Arnold (Maine: University of Maine Darling Marine Centre), 30-38.

Carpenter, R. C. (1981). Grazing by Diadema antillarum (Philippi) and its effects on the benthic algal community. J. Mar. Res. 39, 749-765.

Carpenter, R. C. (1984). Predator and population density control of homing behavior in the Caribbean Echinoid Diadema antillarum. Mar. Biol. 82, 101-108.

Carpenter, R. C. (1985). "Sea urchin mass-mortality: Effects on reef algal abundance, species composition and metabolism and other coral reef herbivores," in Proceedings of the Fifth International Coral Reef Congress (Tahiti), 53-60.

Carpenter, R. C. (1986). Partitioning herbivory and its effects on coral reef algal communities. Ecol. Monogr. 56, 345-363.

Carpenter, R. C. (1990a). Mass mortality of Diadema antillarum.1. Long-term effects on sea-urchin population dynamics and coral reef algal communities. Mar. Biol. 104, 67-77.

Carpenter, R. C. (1990b). Mass mortality of Diadema antillarum.2. Effects on population densities and grazing intensity of parrotfishes and surgeonfishes. Mar. Biol. 104, 79-86. staff of the CARMABI research station for their help and advice and many thanks to Ben Roberts and Alexandra Prebble for fieldwork excellence.

\section{SUPPLEMENTARY MATERIAL}

The Supplementary Material for this article can be found online at: http://journal.frontiersin.org/article/10.3389/fmars. 2016.00063

Carpenter, R. C., and Edmunds, P. J. (2006). Local and regional scale recovery of Diadema antillarum promotes recruitment of scleractinian corals. Ecol. Lett. 9, 268-277. doi: 10.1111/j.1461-0248.2005.00866.x

Chiappone, M., Swanson, D. W., Miller, S. L., and Smith, S. G. (2002). Large-scale surveys on the Florida Reef Tract indicate poor recovery of the long-spined sea urchin Diadema antillarum. Coral Reefs 21, 155-159. doi: 10.1007/s00338-0020232-y

Dame, E. A. (2008). Assessing the effect of artificial habitat structure on translocation of the long-spined sea urchin, Diadema antillarum, in Curacao (Netherlands Antilles). Bull. Mar. Sci. 82, 247-254.

Debrot, A. O., and Nagelkerken, I. (2006). Recovery of the long-spined sea urchin Diadema antillarum in Curacao (Netherlands Antilles) linked to lagoonal and wave sheltered shallow rocky habitats. Bull. Mar. Sci. 79, 415-424.

Edmunds, P. J., and Carpenter, R. C. (2001). Recovery of Diadema antillarum reduces macroalgal cover and increases abundance of juvenile corals on a Caribbean reef. Proc. Natl. Acad. Sci. U.S.A. 98, 5067-5071. doi: 10.1073/pnas.071524598

Fretwell, S. D. (1972). Populations in a seasonal environment. Monogr. Popul. Biol. $5,1-217$.

Fretwell, S. D., and Lucas, H. L. J. (1969). On territorial behaviour and other factors influencing habitat distribution in birds: part 1: theoretical development. Acta Biotheor. 19, 16-36.

Furman, B. T., and Heck, K. L. (2008). Effects of nutrient enrichment and grazers on coral reefs: an experimental assessment. Mar. Ecol. Progr. Ser. 363, 89-101. doi: $10.3354 /$ meps 07442

Gardner, T. A., Cote, I. M., Gill, J. A., Grant, A., and Watkinson, A. R. (2003). Long-term region-wide declines in Caribbean corals. Science 301, 958-960. doi: 10.1126/science. 1086050

Hay, M. E. (1984). Patterns of fish and urchin grazing on Caribbean coral reefs: are previous results typical? Ecology 65, 446-454.

Hay, M. E., and Taylor, P. R. (1985). Competition between herbivourous fishes and urchins on Caribbean reefs. Oecologia 65, 591-598.

Hunte, W., and Younglao, D. (1988). Recruitment and population recovery of Diadema antillarum (Echinodermata, Echinoidea) in Barbados. Mar. Ecol. Progr. Ser. 45, 109-119.

Kohler, K. E., and Gill, S. M. (2006). Coral Point Count with Excel extensions (CPCe): a visual basic program for the determination of coral and substrate coverage using random point count methodology. Comput. Geosci. 32, 1259-1269. doi: 10.1016/j.cageo.2005.11.009

Lee, S. C. (2006). Habitat complexity and consumer-mediated positive feedbacks on a Caribbean coral reef. Oikos 112, 442-447. doi: 10.1111/j.00301299.2006.14247.x

Lessios, H. A. (1988a). Mass mortality of Diadema antillarum in the Caribbean what have we learned? Annu. Rev. Ecol. Syst. 19, 371-393.

Lessios, H. A. (1988b). Population dynamics of Diadema antillarum (Echinodermata, Echinoidea) following mass mortality in Panama. Mar. Biol. 99, 515-526.

Lessios, H. A. (1995). Diadema antillarum 10 years after mass mortality - Still rare, despite help from a competitor. Proc. R. Soc. Lond. B Biol. Sci. 259, 331-337.

Lessios, H. A. (2005). Diadema antillarum populations in Panama twenty years following mass mortality. Coral Reefs 24, 125-127. doi: 10.1007/s00338-0040443-5 
Lessios, H. A., Cubit, J. D., Robertson, D. R., Shulman, M. J., Parker, M. R., Garrity, S. D., et al. (1984). Mass mortality of Diadema antillarum on the Caribbean coast of Panama. Coral Reefs 3, 173-182.

Lessios, H. A., Kessing, B. D., and Pearse, J. S. (2001). Population structure and speciation in tropical seas: global phylogeography of the sea urchin Diadema. Evolution 55, 955-975. doi: 10.1554/00143820(2001)055[0955:PSASIT]2.0.CO;2

Levitan, D. R. (1987). The role of size plasticity on the population ecology of the sea urchin Diadema antillarum. Am. Zool. 27, A145-A145.

Levitan, D. R. (1988a). Factors influencing fertilization success and fecundity in the sea-urchin Diadema antillarum Philippi. Am. Zool. 28, A139-A139.

Levitan, D. R. (1988b). Density-dependent size regulation and negative growth in the sea urchin Diadema antillarum Philippi. Oecologia 76, 627-629.

Levitan, D. R. (1989). Changes in the relative size of the jaws and tests of sea-urchins when food limited. Am. Zool. 29, A172-A172.

Levitan, D. R. (1991). Influence of body size and population density on fertilization success and reproductive output in a free-spawning invertebrate. Biol. Bull. 181, 261-268.

MacCall, A. D. (1990). Dynamic Geography of Marine Fish Populations. Seattle, WA: University of Washington Press.

Miller, M. W., Kramer, K. L., Williams, S. M., Johnston, L., and Szmant, A. M. (2009). Assessment of current rates of Diadema antillarum larval settlement. Coral Reefs 28, 511-515. doi: 10.1007/s00338-008-0458-4

Miller, M. W., Szmant, A. M., Fogarty, N., Fasano, C., Capo, T. R., and Nedimyer, K. (2003). Experimental Outplanting and Transplanting of Diadema antillarum in the Florida Keys: Predation is Limiting Population Recovery. Key Largo, FL: Center for Marine Research and NOAA's National Undersea Research Center.

Miller, R. J., Adams, A. J., Ogden, N. B., Ogden, J. C., and Ebersole, J. P. (2003). Diadema antillarum 17 years after mass mortality: is recovery beginning on St. Croix? Coral Reefs 22, 181-187. doi: 10.1007/s00338-003-0301-x

Morris, D. W. (1989). Density-dependet habitat selection - testing the theory with fitenss data. Evol. Ecol. 3, 80-94.

Mumby, P. J., Hedley, J. D., Zychaluk, K., Harborne, A. R., and Blackwell, P. G. (2006). Revisiting the catastrophic die-off of the urchin Diadema antillarum on Caribbean coral reefs: fresh insights on resilience from a simulation model. Ecol. Modell. 196, 131-148. doi: 10.1016/j.ecolmodel.2005. 11.035

Nedimyer, K., and Moe, M. A. (2003). "Techniques development for the reestablishment of the long-spined sea urchin, Diadema antillarum, on two small patch reefs in the upper Florida Keys," in Joint Conf Sci Restoration Greater Everglades and Florida Bay Ecosystem (Palm Harbour, FL).

Ogden, J. C., and Carpenter, R. C. (1987). Species Profiles: Life Histories and Environmental Requirements of Coastal Fishes and Invertebrates (south Florida): Long-Spined Black Sea Urchin. US Fish Wildlife Service Biol Rep 82(1177) US Army Corps of Engineers, TR EL-82-4: 17.
Randall, J., Schroeder, R., and Starck, W. (1964). Notes on the biology if the echinoid Diadema antillarum. Caribb. J. Sci. 4, 421-433.

Sammarco, P. W. (1982a). Echinoid grazing as a structuring force in coral communities: Whole reef manipulations. J. Mar. Biol. Ecol. 61, 31-55.

Sammarco, P. W. (1982b). Effects of grazing by Diadema antillarum Philippi (Echinodermata, Echinoidea) on algal diversity and community structure. J. Exp. Mar. Biol. Ecol. 65, 83-105.

Sammarco, P. W., Levinton, J. S., and Ogden, J. C. (1974). Grazing and control of coral reef community structure by Diadema antillarum Philippi (Echinodermata-Echinoidea) - Preliminary study. J. Mar. Res. 32, 47-53.

Shepherd, T. D., and Litvak, M. K. (2004). Density-dependent habitat selection and the ideal free distribution in marine fish spatial dynamics: considerations and cautions. Fish Fish. 5, 141-152. doi: 10.1111/j.1467-2979.2004. 00143.x

Steiner, S. C. C., and Williams, S. M. (2006). The density and size distribution of Diadema antillarum in Dominica (Lesser Antilles): 2001-2004. Mar. Biol. 149, 1071-1078. doi: 10.1007/s00227-006-0279-3

Teenstra, M. D. (1986). De Nederlandsch West-Indische Eilanden, Deel I: Curaçao. Herdr. (1977): Amsterdam: S. Emmering.

Van der Hal, N. (2005). Diadema antillarum the Difficult Struggle for Come-Back [BSc]. Amsterdam: University of Amsterdam.

Vansteveninck, E. D. D., and Bak, R. P. M. (1986). Changes in abundance of coral reef bottom components related to mass mortality of the sea urchin Diadema antillarum. Mar. Ecol. Prog. Ser. 34, 87-94.

Vermeij, M. J. A., Debrot, A. O., van der Hal, N., Bakker, J., and Bak, R. P. M. (2010). Increased recruitment rates indicate recovering populations of the sea urchin Diadema antillarum on Curaçao. Bull. Mar. Sci. 86, 719-725.

Weil, E., Losada, F., and Bone, D. (1984). Spatial variations in density and size of the Echinoid Diadema antillarum Philippi on some Venezuelan coral reefs. Bijdragen Dierkunde 54, 73-82.

Williams, S. M., García-Sais, J. R., and Yoshioka, P. M. (2011). Spatial variation of Diadema antillarum settlement in La Parguera, Puerto Rico. Bull. Mar. Sci. 87, 531-540. doi: 10.5343/bms.2010.1041

Conflict of Interest Statement: The authors declare that the research was conducted in the absence of any commercial or financial relationships that could be construed as a potential conflict of interest.

Copyright (c) 2016 Rogers and Lorenzen. This is an open-access article distributed under the terms of the Creative Commons Attribution License (CC BY). The use, distribution or reproduction in other forums is permitted, provided the original author(s) or licensor are credited and that the original publication in this journal is cited, in accordance with accepted academic practice. No use, distribution or reproduction is permitted which does not comply with these terms. 